\title{
Rethinking Directions of Politics and Bureaucracy Post-Neo- Liberalism: an Indonesian Experience
}

\author{
Deddy S Bratakusumah ${ }^{1}$ \\ Ministry of National Development Planning Agency/Bappenas - Indonesia
}

\begin{abstract}
The reforms triggered by the economic crisis that hit Indonesia and a number of other Asian countries in 1998 have resulted in not only an improvement over a system that has been in force for the past 30 years but also fundamental changes. Although reform is born by a spirit of renewal, in response to the failure of the state to develop a system that can generate prosperity and justice for the people, both in the political and economic fields, but in the process has not produced a better relationship system between politics and public administration, which is professional, effective, efficient and free from corruption. This unsuccessfulness is predictable because the administrative reform is not based on a strict economic school. We had previously applied the Keynesian school, then Neo-liberalism, up until now the world is still searching for a new school. No exception for Indonesia. Reform has established a new system, completely different from the previous system, but without consistent ideology and paradigm. The lack of clear direction is the cause of the failure of administrative reform in Indonesia. The paper will analyze the cause of this unsuccessful, and propose recommendations for improvement.
\end{abstract}

Key Words: Indonesia, Politics, Economic Though, Public Administration

\footnotetext{
1 Deddy S Bratakusumah, PhD, is a Senior Planner and Senior Trainer at Ministry of National Development Planning/Bappenas Republic of Indonesia. Email: deddys@bappenas.go.id
} 


\section{Rethinking Directions of Politics and Bureaucracy Post-Neo- Liberalism: an Indonesian Experience}

Deddy S Bratakusumah

\section{Economic Paradigm After World War II}

For the 25 years after World War II (1945-1970), Keynesianism constituted the dominant paradigm for understanding the determination of economic activity. This was the era in which modern tools of monetary policy and fiscal policy were developed. However, in the mid-1970s the Keynesian thrust went into reverse, to be replaced by neoliberalism. Keynesianism and its failure to develop public understandings of the economy that could compete with the neoliberal rhetoric of "free markets."

While the term neoliberalism often denotes a phase within the capitalist order - that is, an era of the transnational expansion of capital accumulation guided by the primacy of the free market. Despite a very real and often harmful impact, the economic changes driven by neoliberalism in any national setting do not break sufficiently from existing conditions of accumulation as to warrant an explanation of these as stemming from a systemic change within capitalism. Rather, neoliberalism is understood here as an ideological justification for a particular set of economic, political, and social policies which, conversely, could be replaced given sufficient challenge to that justification. At the heart of the discourse accompanying neoliberal economic policy is a commitment to human freedom.

The protection of individual freedoms and the enforcement of conditions that are understood to allow these to flourish form the philosophical basis of neoliberal thought. The definition of freedom employed, however, is telling in its grounding in classical liberal understandings of the role of the individual in society. The concept of the individual as a rational consumer who works and spends in order to satisfy quantifiable desires is translated, in neoliberal thought, into an obsession to liberate markets, and thus societies, from any external influence that would inhibit this rational activity.

For more than 20 years, neoliberalism has been associated with the cruelest economic policies to ravage global. So intense has its impact been, and so thorough its program, that reference to neoliberalism among the poor has often replaced the concept of capitalism in explaining severity, exploitation, and suffering.

The common understanding of neoliberalism focuses on three primary axes: (a) privatization, (b) liberalization, and (c) deregulation, that together comprise the core of the Washington Consensus, the blueprint for national economic policy and transnational activity that has governed such matters since the mid-1980s (Williamson 1990).

Yet, while these three aspects of neoliberalism have indeed guided much decision making and affected the lives of millions of citizens in their wake, it is the position that a move to liberalized trade and state management is in fact not the primary concern of neoliberal policies or their advocates. Instead, it will be argued, neoliberalism is largely an ideological doctrine that has been selectively applied in order to achieve goals that are flexible to immediate conditions but always composed with class interests in mind. 
The global recession of 2008 has challenged more than twenty years of beliefs about free markets and global trade, thereby necessitating a rethinking about the role of governments in promoting policies such as deregulation and privatization. This crisis marking the end of the neoliberal economic thought. To this end Stiglitz (2019) mention:

"The neoliberal experiment - lower taxes on the rich, deregulation of labor and product markets, financialization, and globalization - has been a spectacular failure. Growth is lower than it was in the quarter-century after World War II, and most of it has accrued to the very top of the income scale. After decades of stagnant or even falling incomes for those below them, neoliberalism must be pronounced dead and buried."

Since theories of the economy, politics, and public administration are interrelated. As a consequence, there are also the movement to find the best suitable public administration, amid the advance of democracy, and beyond neoliberalism economic.

How the position or role of public administration, which is often represented with the bureaucracy, in a democratic country is not only the Indonesia problem. As said by Meier and O'Toole Jr (2006): "One of the most important and persistent challenges of modern government is how to reconcile the demands of democracy with the imperatives of bureaucracy."

\section{Bureaucracy in Indonesia}

Talking about bureaucratic problems must begin with an understanding of the bureaucracy itself. We know something if we see and feel it. If we ask ordinary people what is bureaucracy? then what comes out of their mouth is everything that is done by the bureaucracy and all the impacts that are felt by the community. The most memorable thing is, of course, that involves bad and unfair treatment of the bureaucracy. Especially the actions of the public bureaucracy or in Indonesia are known as government apparatus. Thus the bureaucracy in the minds of ordinary people is imaged as something long-winded, often meetings, often seminars, talkative, blaming each other, like to make various committees, rubber clocks, waste of time, inefficient and corrupt. Although not all bureaucrats in the public bureaucracy have such an image.

Bureaucracy can literally be interpreted as "Rule by Officials" (Heywood, 2002) or in Indonesian means "regulated by officials." Meanwhile, the bureaucracy itself is actually not only found in the public sector but also in the private sector. Many of the definitions put forward by experts and thinkers about this bureaucracy, the classic notion of bureaucracy which is most famously stated by Max Weber, among others, he said about bureaucracy is:

"... organizations that have certain functions that are regulated by regulations ... this organization adheres to the principles of the hierarchy ...... units under, controlled and controlled by their superiors ... administrative provisions, decisions, and regulations are written down and recorded in writing ... "

From these various definitions, Garston (1993) tries to interpret bureaucracy as:

"A bureaucracy is an organizational structure characterized by a hierarchy whose occupants are appointed, whose lines of authority and responsibility are set by known rules (including precedents), and in which justification for any decision 
requires references to known policies whose legitimacy is determined by authorities outside the organizational structure itself."

Therefore we can interpret that bureaucracy is an organization that has a level, each level is occupied by an official who is appointed or appointed, accompanied by rules about his authority and responsibilities, and every policy made must be known by the creditor. Mandates here, in the private sector, are shareholders or represented by commissioners, while in the public sector are the people represented by members of parliament who are elected to represent them.

Analysis of this bureaucracy although for social experts is a relatively new thing (Garston 1993), but with our various understandings and deepening, bureaucracy has existed almost as long as human civilization itself. Anyone who analyzes the Roman Empire, how the Egyptians built the pyramids, and the ancient irrigation system, the Javanese built Borobudur, the system of government of the Majapahit kingdom that had control from Merauke to Madagascar from Brunei to Blitar, the system of Srivijaya royal government, people Chinese people build the Great Wall and the various realities of the history of a government can certainly be in contact with and must analyze bureaucratic problems

On this occasion, the analysis of the bureaucracy is limited only to the bureaucracy in the public sector. Given the existence of bureaucracy in the public sector when the government must provide public goods and services (goods and services), where goods and services will not be provided by the private sector because it is not in accordance with the market mechanism. Even in certain circumstances these public goods and services have a tendency to be natural monopoly. Therefore the public sector bureaucracy is often known as a public servant.

Thus what is expected from the public sector bureaucracy is the service and provision of government goods that fulfill the aspirations and desires of the people. As simple as that is the understanding or expectation of ordinary people for the public bureaucracy. Although the actual meaning of "service" here in the broadest sense. Actually the role of the bureaucracy is not only limited to those who are in the front liner such as KTP maker officers, SIM makers, passport-making officers, goods inspection officers, civil service police, field traffic police, permit makers, and various officers who deal directly with the community. However, they are a window of the overall bureaucratic attitude and behavior. Their bad is also the image of the entire public bureaucracy. In fact, due to this storefront, the image of the public bureaucracy is not as encouraging as it was stated before.

Sharing these decades of public bureaucracy has made the public bureaucracy worse in Indonesia. Some government regimes have been and are being witnessed, that the orientation of services from the public bureaucracy has gone away with power. The public bureaucracy has made itself a ruler rather than as a servant. The classic Indonesian paradigm of bureaucracy is very noble and has been known for centuries, namely "civil service" has shifted to "pangreh praja". The aspirations and desires of the people are very far from what they do, they are more concerned with the interests of their leaders or groups, even later they are more concerned with their groups or parties. That is the picture of the daily reality of the public bureaucracy in Indonesia. Although once again not all bureaucrats behave this way.

The role of the public bureaucracy is actually not only to provide public services in a narrow sense but to play a role in managing public policy (public policy management). Public bureaucracy plays a role in the process of formulating or 
making public policy, its implementation and enforcement, and its evaluation. From the roles of the public bureaucracy, what the "front-liners" do is actually only a small part of the implementation of public policy. For example, the train ticket window clerk, they just run a small part of the end of public policy about the transportation system, and many other examples are around us.

The plural role (multi roles) of public bureaucracy has also become the material of thought for experts to define it, Joyce (2001) for example explaining the role of the public bureaucracy as follows:

"Civil servants perform a variety of roles in liberal democratic states, but there are two which have traditionally been emphasized: they give advice to those who exercise control of the political arm of the executive branch on the content of policy; they may also be responsible for implementing it. The implementation of the policy is carried out at all levels of government and includes the delivery of a service to the public (such as payment of welfare benefits)".

Public bureaucracy has a very important and heavy role in managing public policy. Public bureaucrats in this case professional career bureaucrats have had a lot of experience in managing public policy, and this valuable experience cannot be matched by politicians and other political officials. Public bureaucrats are professionals who voluntarily devote their lives to bureaucracy. They are not elected (non-elected) but apply to run their careers in the public bureaucracy.

The experience and competence of public bureaucrats are often ignored in the arena or discourse of the nation's state life. It is as if the state will not exist without politicians, even though the reality is the opposite. The government will only be able to be run by professional bureaucrats who indeed have a career in that field. In connection with that, it can be said that Public Bureaucracy is the fourth pillar in a democratic country after the Legislature, Judiciary and Executive, in this case, the executive is political officials or state officials.

\section{The Paradigm of Bureaucratic System in Indonesia Since its Independence}

Years after gaining independence, in 1945-1949, public administration functioned, as a legacy of the colonial, but its main role was to support the struggle to uphold and maintain the country's independence and sovereignty.

In the period of liberal democracy, in 1950-1959, public administration became the arena for the struggle of the influence of political parties. Many bureaucracies are involved in practical political activities. The unstable political and governmental situation influences the effectiveness of public administration, especially the cabinet that has fallen up and hampers the administration of government tasks properly. Even so, the state apparatus has functioned and became a powerful vehicle to support the integrity of the unitary state, and was able to provide government services to the community to the village level and to reach all corners of the country.

During the period of guided democracy, in 1959-1965, the bureaucracy had not changed much. With the expansion of the cabinet, the bureaucracy grew larger. On the one hand, developing country apparatus is getting bigger and stronger because of the increasing role of the state, both in political and economic life. On the other hand, representative and oversight institutions established by the constitution have blended into government apparatus, and their leaders have become members of the cabinet. As a result, the monitoring function is weak. There is also overlap and confusion between authority and responsibility, including between central and 
regional government agencies, as well as between vertical agencies in the regions and local government agencies.

From 1966 to 1998, or known as the New Order era, the bureaucracy merged with power (single loyalty). The authoritarian government-produced: (a) political stability, (b) economic growth, and (c) equity and poverty reduction.

In the early days of the reform, starting in 1998, the position of the state apparatus was confirmed as an adhesive element of a professional, reliable and neutral nation of political interests. In the midst of such high political dynamics, the independence of civil servants who in the past had sided with the ruling party was upheld so that the wheels of government could run free from the politicization of the bureaucracy.

The timeline of the interaction between politics, economic though, and public administration since the beginning of Indonesian independence and beyond, is shown in Figure 1.

Figure 1. Indonesian Politics, Economic Thought, and Public Administration

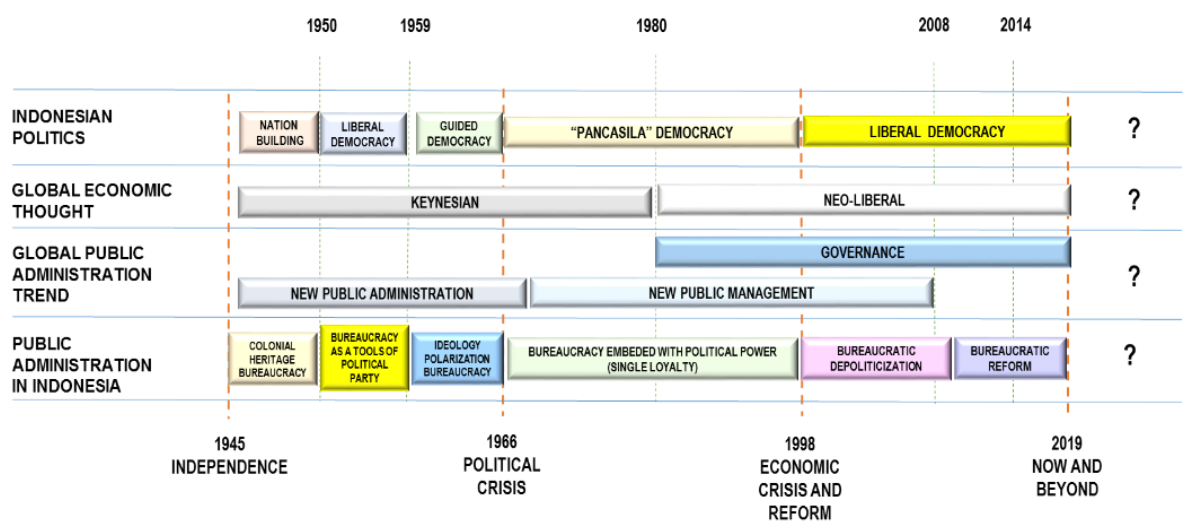

Figure 1. Indonesian Politics, Economic Thought, and Public Administration

Source: Own Analysis

\section{Moving Beyond}

Whatever the analysis ultimately aims to emphasize how important and crucial the existence of the Public Bureaucracy is. While looking for and anticipating the development of global economic thinking, Indonesia has to think and rethink the future of public administration based on various experiences since Indonesia's independence.

The future of the public administration in Indonesia will concern with various aspects and elements related to one another. These aspects include:

\section{Reviewing Government Functions}

This is the first step that must be done. Along with the development of economic thought, the role and function of the government must be reviewed to be agreed upon. Some ideas about this are that the function of the government is only to protect the people who are not fit in the market mechanism (the poor) and provide goods and services that cannot be provided with market mechanisms. Another functions are providing public goods, and enacting regulations. 


\section{Philosophy of Public Administration}

The public administration philosophy must be reviewed. Base on this philosophy the next steps for improving public administration will be carried out. For example, are we still adhering to a very hierarchical Weberian or do we adhere to another philosophy? The selection and determination of the philosophy is very important so that all improvements or developments have the same rationale.

\section{Organizational Structure}

From reciting the function of government that has been adjusted to the situation and conditions of life of the nation-state, by also paying attention to the external and internal strategic environment, the organization of the public bureaucracy can be formed by dividing the functions of the government. Thus a proper organizational structure will be created and in accordance with the rationale and function of the government.

\section{Revision Laws and Regulations}

To carry out the steps above, it is necessary to review and adjust the existing laws and regulations regarding the public administration, which involves various aspects of their existence up to their functions and authorities.

\section{Apparatus Resource Policy}

The next step in improving public administration is regarding human resources. Improvement does not mean starting from scratch but adjusting here and there. This means that the existing HR is then adjusted to the need for competency in a position on the organizational structure of the improved public bureaucracy. In the future, this policy regarding HR involves; (1) procurement, (2) coaching including career and welfare, and (3) enhancing competence.

\section{Management of Bureaucratic Improvement}

In order for this public bureaucratic improvement to succeed, management is needed. As the basis of this change management is a Grand Design of the Improvement of Public Bureaucracy which must be stated in the form of legislation. This includes determining who is leading the improvement of this public bureaucracy.

Finally, the improvement of the public bureaucratic system must also be emphasized to the improvement of bureaucratic human welfare, in this regard is the Civil Servants. So far the concern for improving the welfare of public bureaucrats does not have a comprehensive basic pattern. The policies carried out are only informal and even reactive.

The well-being of public bureaucrats includes the rights that must be obtained by public bureaucrats, including salaries and other benefits.

Welfare does not have to be interpreted as salary. Salary is only one tool to improve the welfare of public bureaucrats. Salary as a tool to improve the welfare of public bureaucrats has resulted in a "psychological effect" on macroeconomics in Indonesia. This happened because, for decades, the issue of salary increases had become a political commodity. As a result, salary increases announced three months earlier (together with the submission of government financial notes) of for example $10 \%$, have resulted in an increase of $10 \%$ in the essential good prices, in the month of the announcement. As a result, three months later the purchasing power of public bureaucrats did not improve. 
The well-being of public bureaucrats can be carried out by beginning with the improvement of the salary structure, minimum and maximum and differences for each level, then establishing periodic increases that are sufficient without being announced or politicized. And what is important is the provision of various guarantees or insurance for public bureaucrats, these benefits will, in turn, make the public bureaucrats work diligently and increase productivity.

Benefits among the most basic are (1) Education for children up to the level of high school, (2) Health services, (3) Ownership of House, and (4) Old-age security. The benefits in some parts are not new but need to be improved.

By applying for these benefits by insurance system to improve the welfare of public bureaucrats, the burden on the state budget will not be as large as if the benefits is provided by the government itself. The government simply subsidizes the "premium" for the insurance or even can be deducted from the salary, after the salary structure is improved.

Such is the analysis and policy proposal on the problems we face regarding the development of public administration in Indonesia. All decisions certainly carry risks. But now is the time for us to decide to improve the image and performance of the public bureaucracy through conceptual and comprehensive improvements. Let's make improvements now. It's now or never.

\section{Concluding Remarks}

Advancing Democracy, while awaiting the post neoliberalism economic thought, the development of public administration in Indonesia needs to be accelerated. Many ideas have been developed scientifically on the basis of empirical experience, which we can apply to our administrative system, of course by recognizing things that are specific to our nation.

Indonesia has to find the right pattern of political-bureaucratic relations, so as to support the improvement of the quality of democracy and at the same time maintain integrity, competence and neutrality bureaucracy.

Administrative reform must be improved, the approach must be innovative and not necessarily fixed on the old paradigm, which is dominated by the approach to standard rules, structure, and hierarchy.

\section{References}

Barnard, Chester. The Functions of the Executive. Cambridge, MA: Harvard University Press. Belknap Press. 1938.

Bertucci, Guido and Adriana Alberti. "Globalization and the Role of the State: Challenges and Perspectives", Reinventing Government for the TwentyFirst Century, State Capacity in a Globalizing Society. Kumarian Press Inc., 2003.

Dahl, Robert A. Preface to Democratic Theory. University of Chicago Press. Chicago. 1970.

Fredericson, H. George. New Public Administration. Tuscaloosa: University of Alabama Press. 1980.

Garston, Neil H. Bureaucracy: Three Paradigms. Kluwer Academic Publishers. London. 1993.

Golembiewski, Robert T. Organization Development in Administration. Editor: Robert T. Golembiewski and William B. Eddy. New York, Marcel Dekker, 1978.

Joyce, Peter. Politics. Hodder \& Stoughton, Ltd. London. 2001. 
Hood, Christopher. Public Administration and Public Policy: Intellectual challenges for the 1990s. Australian Journal of Public Administration. 1989.

Marini, Frank. Toward a New Public Administration: Minnowbrook Experiment. Scranton, Penn: Chandler Publishing Co., USA. 1971.

Meier, Kenneth J. and Laurence O’Toole Jr. Bureaucracy in a Democratic State: A Governance Perspective. John Hopkins University Press. Baltimore. 2006.

Osborn, David and Ted Gaebler. Reinventing Government. A Plume Book. 1992.

Rondinelli, Dennis A., And G. Shabbir Cheema. Reinventing Government for the Twenty-First Century: state capacity in a globalizing society. Kumarian Press, Inc., Blue Hills Avenue, Bloomfield, USA. 2003.

Rosenbloom, David H., and Robert S. Kravchuk. Public Administration: Understanding Management, Politics, and Law in the Public Sector. McGraw Hill. Boston. 2005.

Simon, Herbert A. Public Administration. New York: Alfred A. Knoff. 1947.

Shah, Anwar. Local Governance in Developing Countries (Public Sector Governance and Accountability Series). World Bank. Washington DC. 2006.

Stigler, George. The Tenable Range of Functions of Local Government. In U.S. Congress, Joint Economic Committee, ed., Federal Expenditure Policy for Economic Growth and Stability. Washington, D.C. 1957.

Stiglitz. Joseph E. After Neoliberalism, Project Sindycate, Washington, D.C. 2019

Weber, Max. Essays in Sociology. Translated and editet by H.H. Gerth and C. Wright Mills. Oxford: Oxford University Press. 1946.

Williamson, John, "What Washington Means by Policy Reform," Latin American Adjustment: How Much Has Happened? Washington: Institute for International Economics, 1990.

Wilson, Woodrow. The Study of Administration, dalam Political Science Quarterly. 2 Juni 1887. 